УДК 376:792-053.2(045)

https://doi.org/10.52058/2786-4952 -2022-1(6)-97-108

Васильєва Марина Петрівна доктор педагогічних наук, професор, завідувач кафедри соціальної роботи і соціальної педагогіки, Харківський національний педагогічний університет імені Г.С. Сковороди, факультет психології і соціології, кафедра соціальної роботи і соціальної педагогіки, вул. Чернишевської, буд. 60, каб. 6, м. Харків, 61002, тел.: (057) 702-66-15, https://orcid.org/0000-0002-2765-1220

Романова Інна Анатоліївна доктор педагогічних наук, доцент, професор кафедри соціальної роботи і соціальної педагогіки, Харківський національний педагогічний університет імені Г.С.Сковороди, факультет психології i соціології, кафедра соціальної роботи i соціальної педагогіки, вул. Чернишевської, буд. 60, каб. 6, м. Харків, 61002, тел.: (057) 702-66-15, https://orcid.org/0000-0002-5318-8970

Шеплякова Ірина Олександрівна кандидат педагогічних наук, доцент кафедри соціальної роботи і соціальної педагогіки, Харківський національний педагогічний університет імені Г.С.Сковороди, факультет психології i соціології, кафедра соціальної роботи і соціальної педагогіки, вул. Чернишевської, буд. 60, каб. 6, м. Харків, 61002, тел.: (057) 702-66-15, https://orcid.org/0000-0002-1098-3480

\title{
АКТУАЛЬНІСТЬ ВИКОРИСТАННЯ ЗАСОБІВ ТЕАТРАЛЬНОГО МИСТЕЦТВА В СОЦІАЛЬНОМУ ВИХОВАННІ ПІДЛІТКІВ У ЦЕНТРАХ СОЦІАЛЬНО-ПСИХОЛОГІЧНОЇ РЕАБІЛІТАЦЇ̈ ДІТЕЙ
}

Анотація. У сучасних умовах актуальною суспільною потребою $\epsilon$ підвищення ефективності соціально-виховної роботи в центрах соціальнопсихологічної реабілітації дітей з вихованцями підліткового віку з формування їхної соціальності. Саме соціальне виховання $є$ визначальним у процесі становлення та розвитку особистості, оскільки спрямоване на формування в дитини ієрархії соціальних цінностей, соціальних якостей, просоціальної поведінки. При цьому дієвими суб'єктами соціально-виховного процесу в зазначених соціальних інституціях, від професійних дій яких залежить його ефективність, є соціальні педагоги. Від використання фахівцями арсеналу методів, засобів організації соціально-виховної діяльності з підлітками, які перебувають у складних життєвих обставинах, залежить ефективність соціального виховання вихованців. У статті розкрито особливості дітей підліткового віку, що перебувають в центрах соціально-психологічної реабілітації дітей, їхні потреби; уточнено суть поняття «соціальне виховання 
підлітків у центрах соціально-психологічної реабілітації дітей».

Зважаючи на доведений потенціал засобів театрального мистецтва у соціальному вихованні особистості, що виражається в ігровій природі сценічної дії, синтезі багатьох видів мистецтв, колективному характері театральної творчості, схарактеризовано актуальність використання цих засобів у роботі з підлітками в центрах соціально-психологічної реабілітації дітей. Розкрито форми роботи, спрямовані на активізацію соціального розвитку вихованців з метою підвищення рівня їхньої соціальності. Основні методи, використані в дослідженні, - теоретичний аналіз, синтез, систематизація, узагальнення, порівняння.

Ключові слова: соціальне виховання, соціальність, підліток, центр соціально-психологічної реабілітації дітей, театральне мистецтво, засоби.

Vasylieva Maryna Petrivna Doctor of Pedagogical Sciences, Professor, Head of the Department of Social Work and Social Pedagogy, H. S. Skovoroda Kharkiv National Pedagogical University, Faculty of Psychology and Sociology, Department of Social Work and Social Pedagogy, Chernyshevskaya St., 60, Room 6, Kharkiv, 61002, тел. (057) 702-66-15, https://orcid.org/0000-0002-2765-1220

Romanova Inna Anatoliivna Doctor of Pedagogical Sciences, Associate Professor, Professor of the Department of Social Work and Social Pedagogy, H. S. Skovoroda Kharkiv National Pedagogical University, Faculty of Psychology and Sociology, Department of Social Work and Social Pedagogy, Chernyshevskaya St., 60, Room 6, Kharkiv, 61002, тел.: (057) 702-66-15; https://orcid.org/0000-0002-5318-8970

Shepliakova Iryna Oleksandrivna Candidate of Pedagogical Sciences, Associate Professor of the Department of Social Work and Social, H. S. Skovoroda Kharkiv National Pedagogical University, Faculty of Psychology and Sociology, Department of Social Work and Social Pedagogy, Chernyshevskaya St., 60, Room 6, Kharkiv, 61002, тел.: (057) 702-66-15, https://orcid.org/0000-0002-1098-3480

\section{URGENCY OF USING THEATER ART IN THE SOCIAL EDUCATION OF ADOLESCENTS IN THE CENTERS OF SOCIAL AND PSYCHOLOGICAL REHABILITATION OF CHILDREN}

Abstract. In modern conditions, the urgent social need is to increase the effectiveness of social and educational work in the centers of social and psychological rehabilitation of children with adolescents to form their sociality. It is social education that is decisive in the process of formation and development of personality, as it is aimed at forming in the child a hierarchy of social values, social qualities, prosocial behavior. At the same time, social educators are effective subjects of the social and educational process in these social institutions, on the professional actions of which its effectiveness depends. The effectiveness of social 
education of pupils depends on the use of specialists in the arsenal of methods, means of organizing social and educational activities with adolescents who are in difficult life circumstances. The article reveals the features of adolescent children in social and psychological rehabilitation centers for children, their needs; the essence of the concept «social education of adolescents in the centers of social and psychological rehabilitation of children» is specified.

Given the proven potential of theatrical arts in the social education of the individual, which is expressed in the playful nature of stage action, synthesis of many arts, the collective nature of theatrical creativity, characterized the relevance of using these tools in working with adolescents in the centers of sociopsychological rehabilitation of children. Forms of work aimed at intensifying the social development of students in order to increase their level of sociality are revealed. The main methods used in the study - analysis, synthesis, systematization, generalization, comparison.

Keywords: social education, sociality, adolescent, center of social and psychological rehabilitation of children, theatrical art.

Постановка проблеми. На сучасному етапі розвитку українського суспільства наявною є тенденція до зростання кількості дітей, особливо підліткового віку, які потребують підвищеної уваги щодо їхнього соціального виховання. Це зумовлено впливом різних несприятливих чинників: девальвацією моральних цінностей, виховною пасивністю сімей та неналежним виконанням батьками своїх обов'язків, поширенням негативних явищ (наркоманії, алкоголізму), деморалізуючим впливом засобів масової інформації на свідомість дитини тощо. Проте, саме соціальне виховання, спрямоване на формування в особистості ієрархії соціальних цінностей, соціально важливих якостей, просоціальної поведінки, $є$ визначальним у процесі становлення та розвитку особистості. В його ефективності зацікавленими $\epsilon$ суспільство і держава, які мають реагувати на існуючі прогалини й проблеми.

Так, зважаючи на особливості дітей підліткового віку в разі відсутності виховного впливу з боку сім'ї, неналежне виконання батьками виховних функцій, державою передбачено створення спеціальних соціальних інституцій, зокрема центрів соціально-психологічної реабілітації дітей. На такі центри покладено функції соціального захисту, допомоги і соціального виховання підростаючого покоління, забезпечення потреб дитини. Вихованці центрів, перебуваючи у складних життєвих обставинах, часто мають проблеми в перебігу процесу соціального виховання. У зв'язку з цим, актуальною постає проблема пошуку ефективних методів і засобів організації в центрах соціально-психологічної реабілітації дітей цілеспрямованого, систематичного соціально-виховного впливу на вихованців підліткового віку для формування соціально здорової особистості. Провідну роль у цьому процесі виконують фахівці соціальної галузі - соціальні педагоги. 
Аналіз останніх досліджень i публікацій. Теоретичні питання соціалізації дітей підліткового віку досліджували О. Безпалько, Н. Бурая, Р. Вайнола, М. Галагузова, Л. Міщик, С. Харченко та ін.; соціального виховання - В. Бочарова, М. Васильєва, І. Звєрєва, А. Капська, А. Мудрик, О. Рассказова, А. Рижанова та ін. Теоретико-методичні основи діяльності центрів соціально-психологічної реабілітації дітей розкрито в дослідженнях О. Караман, С. Коношенка, С. Пальчевського, А. Поляничко, М. Сосюри та інших.

Мистецтво як засіб соціального виховання репрезентовано в наукових розвідках І. Беха, Н. Максимовської, О. Мальцевої, Ю. Лисенко, О. Олексюк, В. Олійник, О. Отич, О. Хендрик та інших учених; театральне мистецтво - у працях А. Капської, М. Дергач, Л. Некрасова, Д. Якимовича.

Проведений аналіз розробленості проблематики в науковій літературі показав, що на сьогодні вже накопичено значний теоретичний і емпіричний матеріал $з$ проблеми соціалізації дітей у центрах соціально-психологічної реабілітації.

Узагальнення проведеного аналізу наукових джерел уможливило висновок про те, що театральне мистецтво $є$ дієвим засобом соціальновиховного впливу на людину протягом життя. Ефективне використання його інструментів у процесі соціального виховання підростаючого покоління (у тому числі підлітків - вихованців центрів соціально-психологічної реабілітації дітей) здатне активізувати соціальний розвиток дітей 3 метою підвищення рівня їхньої соціальності, формування необхідних особистісних характеристик.

Водночас в соціально-педагогічній літературі не отримала достатнього висвітлення проблема використання засобів театрального мистецтва в процесі соціально-виховної роботи з підлітками в зазначених соціальних інституціях.

Мета статті - визначити актуальність використання засобів театрального мистецтва в процесі соціального виховання підлітків у центрах соціальнопсихологічної реабілітації дітей.

Виклад основного матеріалу. Провідними положеннями дослідження соціального виховання особистості стали такі: «виховання $\epsilon$ апріорі соціальним, а його результат (засвоєння особистістю соціально-культурного досвіду, включення індивіда в діяльність і суспільні відносини) - реалізацією соціальної функції суспільства» [1, С. 12]; соціальне виховання - це «система соціально-педагогічних, культурних, сімейно-побутових та інших заходів, спрямованих на оволодіння та засвоєння дітьми та молоддю загальнолюдських та спеціальних знань, соціального досвіду 3 метою формування у них сталих ціннісних орієнтацій та адекватної соціально спрямованої поведінки» [2, С. 25]; результатом соціального виховання особистості є соціальність - «ієрархія соціальних цінностей, соціальних якостей, просоціальної поведінки людини» [3, С. 98].

Науковцями визначено особливості підлітків - вихованців центру 
соціально-психологічної реабілітації дітей як «закладу соціального захисту, що створюється для тривалого (стаціонарного) або денного перебування дітей віком від 3 до 18 років, які опинились у складних життєвих обставинах для надання їм комплексної соціальної, психологічної, педагогічної, медичної, правової та інших видів допомоги» [4]. Зокрема, за результатами наукового дослідження «Діти у складних життєвих обставинах» [4], установлено, що в зазначеної категорії дітей, здебільшого, є незабезпеченими такі базові потреби, як: біогенні (повноцінне харчування, достатній і спокійний сон, відпочинок, розвиток моторики, фізична активність тощо, «задоволення яких забезпечує фізичне здоров'я дитини» [4]), психогенні (емоційно-ціннісний, інтелектуальний, естетичний розвиток дитини, самоусвідомлення) та соціогенні (сімейне благополуччя, любов батьків, спілкування, співпраця, дружба i кохання, самоствердження). При цьому погоджуємося 3 думкою авторів дослідження, що «для гармонійного розвитку дитини необхідно формувати саме соціогенні та психогенні потреби вищого порядку, оскільки 3 віком саме вони будуть визначати поведінку дитини» [4].

На основі аналізу наукової концепції М. Сосюри [5], О. Рассказової [6] «соціальне виховання підлітків у центрах соціально-психологічної реабілітації дітей» визначено як процес їхньої спрямованої, закономірної позитивної зміни, вдосконалення соціально значущих якостей, засвоєння соціальних емоційних реакцій; напрацювання різних форм самовиявлення в різних видах соціальної поведінки, звичних реакцій у певних соціальних діях, усвідомлення себе суб’єктом власної діяльності.

Установлено, що в центрах як спеціально створених державою соціальних інституціях забезпечується надання підліткам, які опинилися в складних життєвих обставинах, професійної комплексної допомоги (соціальної, психологічної, педагогічної, медичної, правової), а також здійснюється соціальний захист, соціально-педагогічна підтримка, зокрема через створення умов для їхньої успішної соціалізації, задоволення потреб, розкриття творчого потенціалу та самореалізації в процесі реабілітації. При цьому серед першочергових завдань соціальних педагогів центрів $є$ «допомога у зайнятті значущої соціальної позиції й усвідомленні власного «Я», подоланні інфантилізму, егоїзму, духовної спустошеності; сприяння становленню дитини як суб'єкта життя, який володіє мистецтвом пізнання самого себе, компетентністю ...; відновлення ... дитини засобами зміни іiі особистості, зрушення в емоційній сфері (подолання наслідків переживань, невпевненості у своїх силах)» [6].

Театральне мистецтво як синтез мистецтв (літератури, мистецтва дії i звучання слів, образотворчого мистецтва, музики, хореографії тощо) має унікальні можливості впливу на свідомість і почуття підлітків, сприяння їхньому етичному, естетичному вихованню, «певному витонченню внутрішнього світу, духовному зростанню, розкриттю та розвитку задатків, творчих здібностей, обдаровань» [7]. 
На основі аналізу джерельної бази з'ясовано, що театральне мистецтво загалом і театр мають виражений соціальний характер, а взаємодія акторів і зали - «як система колективної діяльності, у якій не тільки реалізується соціальний контроль, а й відбувається оволодіння особистістю глядача системою соціальних ролей, соціальним досвідом, що і визначає функцію театру як способу регулювання соціальних процесів та освоєння загальної культури і комунікації» [8, С. 11]. Отже, театральне мистецтво має потенціал для соціального виховання особистості i може використовуватися цілеспрямовано для певних цілей з формування особистості.

У дослідженні І. Зязюна наголошено на «вагомій ролі театрального мистецтва, його образної системи в актуалізації як у глядачів, так і у виконавців цінностей людського життя і духу» [9, С. 22]. У наукових розвідках В. Шахрай репрезентовано театральне мистецтво як «чинник оптимізації взаємодії особистості та соціуму» [10]. У цілому, науковцями проаналізовано суть театру як засобу впливу на культурне та соціальне становлення особистості, розкрито теоретичні підходи щодо ролі театрального мистецтва у процесі регуляції соціальних взаємин, удосконаленні міжособистісної взаємодії, що сприяє оптимізації буття соціуму.

Разом 3 тим з'ясовано, що в педагогічних (зокрема й соціальнопедагогічних) наукових джерелах театральне мистецтво здебільшого визначалося як другорядний (додатковий) засіб впливу на особистість, який, в основному, впливає на формування виключно іiі морально-естетичних цінностей. Проте останнім часом спостерігається зміна у ставленні науковців до засобів театрального мистецтва. Так, аналізуються можливості використання театрального мистецтва (театру) як одного із засобів: підвищення ефективності процесу реабілітації хворих, зважаючи на те, що «театральне мистецтво може виконувати деякі арт-терапевтичні функції, а саме: катарсистичну (очищення, звільнення від негативного стану); регулятивну (зняття нервово-психічного напруження, моделювання позитивного психоемоційного стану); комунікативно-рефлексивну (формування адекватної міжособистісної поведінки)» [11]; профілактикокорекційної роботи, зважаючи на те, що рефлексія, яка супроводжує театральну гру, надає іiі учаснику «ефективні інструменти власної корекції особистісних поведінкових стереотипів» [12, С. 372].

Отже, можливості використання театрального мистецтва в процесі становлення особистості, зумовлені специфікою театру, що виражається в ігровій природі сценічної дії, синтезі багатьох видів мистецтв, колективному характері театральної творчості, на сучасному етапі значно розширюються.

Варто відзначити, що в основу кожного витвору театрального мистецтва (вистави) покладено драматичний твір, який є синтетичним жанром: це i літературний, і сценічний твір. Джерелом дії у творі $є$ конфлікт (як певне протиріччя, найчастіше, у поглядах різних персонажів). Конфлікт змушує героїв діяти, виявляючи власні характери, життєві позиції. Актори, своєю 
чергою, повинні не просто відтворити цей конфлікт, а й усвідомити власне ставлення до нього. Так, творче ставлення до подій вистави сприяе виробленню (як у акторів, так і в глядачів) власних уявлень про життя, розвитку почуттів, вольових якостей, формуванню позитивної самооцінки та ціннісної спрямованості на творчість, самопізнання, соціальну активність. Таким чином, театр реалізує «соціальну сутність людини в іiі спонтанності та вільному прояві почуттів і творчої уяви, який завжди передбачає винесення їх на публіку, передачу глядачеві й встановлення із ним емоційно-почуттєвого контакту, в якому реалізуються очікування актора на емоційну зворотну реакцію залу - потужний стимул як акторської творчості, так і процесу іiі сприймання» [13, С. 57].

Завдяки можливості впливати на людську свідомість, декларуючи певні духовні цінності, театр як вид мистецтва опосередковано (через створювані художні образи) може впливати і змінювати як масову свідомість загалом, так і поведінку окремої людини в соціумі зокрема. Через це театральне мистецтво від початку виникнення використовувалося як ефективний засіб регуляції соціальних процесів, колективних дій, індивідуальної поведінки. Ще стародавні обряди і ритуали (як прообраз театру) «виконували надзвичайно важливу соціальну функцію - згуртування членів спільноти, консолідацію їхніх зусиль на досягнення певної мети i, що найголовніше, формування відчуття приналежності до Цілого» [14]. Виходячи 3 цього, театральне мистецтво визнається найбільш соціальним з усіх видів мистецтва, адже, поперше, становить собою «концентрацію фундаментального людського досвіду» [10]; по-друге, є неможливим без спілкування акторів між собою й залом; по-третє, «здатне об'єднати думки, почуття, устремління та волю багатьох людей, «заражати» їх спільним переживанням» [10]. Водночас йому притаманна «здатність поєднувати індивідуальний i соціальний виміри людського буття, адже соціальне розглядається в ньому крізь призму індивідуального сприйняття і відчуття» [10].

Узагальнюючи, зазначимо: театр як художнє явище, як творчий організм, де переплетеними є різні види людської діяльності (художньої, виробничої, комунікативної, організаторської, ігрової), надає необмежену можливість фахівцям соціальної галузі в створенні необхідних умов для культурного, морального, фізичного розвитку особистості. Підтвердженням цього $є$ висновок $з$ аналізу наукових джерел і практики соціально-виховної роботи, зокрема в центрах соціально-психологічної реабілітації дітей, який засвідчив, що соціальні педагоги використовують засоби театрального мистецтва в таких формах, як: вправи із сценічної майстерності в процесі ігрової взаємодії; використання елементів мистецтва словесної дії під час організації концертної самодіяльності; проведення літературних вечорів, театралізованих вистав на актуальну соціально-виховну тематику («театральні агітки»); відвідування театру, перегляд вистав 3 подальшим їх обговоренням; театральний гурток (студія). 
Журнал«Герстективи та інновації наукиљ

(Серія «Гедагогіка», Серія «Гиихологія», Серія «Медицинв»

№(6) 2022

Такі форми $є$ актуальними для просоціального розвитку дітей підліткового віку, оскільки передбачають створення сприятливого соціокультурного середовища (в якому можна спілкуватися, ділитися почуттями, обмінюватися досвідом, дізнаватися про щось нове тощо). При цьому для підлітків надзвичайно важливим $є$ й те, щоб колектив, частиною якого вони $\epsilon$, розумів і підтримував їх на основі спільних інтересів.

Так, для підлітка під час використання засобів театрального мистецтва як колектив виступають учасники театрального гуртка. Слід зазначити, що роль театрального колективу як творця оригінальних творів мистецтва або їх інтерпретатора має відносну цінність, адже на перший план виступає проблема його соціально-педагогічної спрямованості на виконання соціально-виховних завдань (так би мовити «надзавдання»). Останні реалізуються, насамперед, через спрямування роботи колективу театрального гуртка на досягнення спільної мети на основі консолідації зусиль як керівника (яким може бути соціальний педагог Центру), так і учасників колективу.

При цьому надзавдання закладається «всередину» діяльності театрального колективу, органічно вплітається в іiі зміст. Його реалізація вимагає від керівника (соціального педагога) особливого дару - розвиненого педагогічного перспективного мислення, майстерності, чуття i бачення розвитку особистості, здатності проєктувати цей процес, надавати соціальновиховної спрямованості всій навчально-творчій та репетиційній роботі, поєднувати розвиток технічних, художньо-виконавських навичок учасників та їхній морально-естетичний розвиток, формувати загальну культури поведінки, забезпечувати узгодженість дій. Зважаючи на те, що колектив має постійно рухатись уперед (за А. Макаренком), досягаючи все нових і нових успіхів, необхідною $€$ організація перспективних спрямованостей вихованців, визначення цілей, що постійно ускладнюються, та перспектив, які захоплюють.

Це передбачає необхідність майстерного поєднання засобів театрального мистецтва, які підсилюють сценічну дію, передаючи почуття виконавців, рухаючи дійство вперед. Тому в процесі підготовки театралізованих вистав соціально-виховного спрямування соціальному педагогові необхідно зосередити увагу на доборі ефективних засобів і прийомів активізації дії та емоційного впливу на учасників і глядачів.

Варто відзначити, що особливий вплив на емоційний стан чинить музика, яка може бути використана «як у формі окремого номеру (гра на музичному інструменті), так і в якості фону» [7, С. 62] (наприклад, музичний супровід під час перегляду слайдів на соціальну тематику). Дієвим прийомом також $є$ демонстрація кінофрагментів у театралізованому дійстві, яка дає «можливість швидко переноситись в різні періоди історичних і соціальних подій і стати їхнім учасником» $[15$, C. 48]. Соціально-виховний потенціал використання хореографії в театральній виставі (сольний танець, дуетний, груповий, масовий; класичний та естрадний) полягає в тому, що хореографом- 
постановником можуть бути «створені соціальні образи людини, які сприятимуть поглибленню уявлень глядача про індивідуальні та суспільні проблеми людства ... аналіз специфічних особливостей цих образів людини сучасного соціокультурного середовища, безумовно, сприяє розвитку соціальності глядачів» [16, С. 132]. Соціальним педагогом можуть бути використані такі засоби, як: «мистецтво слова, пантоміма, елементи ілюзії, клоунада, акробатика, художня гімнастика тощо» [17]. Дієвою і актуальною формою використання засобів театрального мистецтва в роботі з підлітками $\epsilon$ інтерактивний театр, зокрема форум-театр, театр «рівний-рівному», який дає можливість особистісного проникнення й власної участі у розмірковуваннях над соціально важливими проблемами суспільства, вироблення власного усвідомленого ставлення до них.

Отже, така форма як театральний гурток у центрі соціально-психологічної реабілітації в роботі 3 підлітками дозволяє використовувати засоби театрального мистецтва комплексно. Відвідуючи театральний гурток, підлітки отримують можливість глибше пізнати самих себе, відчути задоволення від причетності до здійснення театральної діяльності, радість подолання особистісних труднощів та відчуття приналежності до колективу тощо. Використання засобів театрального мистецтва в процесі соціально-виховної роботи з підлітками сприяє усвідомленню ними себе частиною суспільства, власної ролі в ньому та місії, вибудовуванню стратегї особистого і суспільного життя, опануванню просоціальних моделей поведінки, активізації прагнення до самореалізації в позитивних соціально корисних видах діяльності. А ще - вихованню в них дисциплінованості, здатності до ефективної взаємодії з колективом, лідерських якостей, готовності підтримати один одного, а головне - бажання змінитися та проявити себе. Адже ігрова природа сценарної дії сприяє розвитку ініціативи і самодіяльності, створює атмосферу свободи, впевненості в собі, творчого розкріпачення та умов для саморозвитку.

Висновки. Урізноманітнення інструментарію соціально-виховної роботи 3 підлітками в центрах соціально-психологічної реабілітації дітей засобами театрального мистецтва здатне активізувати соціальний розвиток вихованців та підвищити рівень їхньої соціальності. Зокрема, це сприятиме: зниженню рівня тривожності дітей, стабілізації їхньої емоційно-ціннісної сфери; підвищенню самооцінки; формуванню в підлітків позитивного ставлення до інших людей на основі усвідомлення шляхів попередження і подолання конфліктів, освоєння принципів позитивного спілкування і взаємодії; розуміння соціально схвалюваних шляхів самореалізації; формуванню прагнення до самоствердження через позитивні вчинки; розвитку пізнавальнотворчої активності підлітків, усвідомленню ними власної ролі як творця особистого життя; розвитку здатності до самореабілітації. 


\section{Лimepamypa:}

1. Бочарова В. Г. Социальная педагогика: диалог науки и практики. Педагогика. 2003. № 9. С. 3-9.

2. Коваль Л. Г., Звєрєва І. Д., Хлєбік С. Р. Соціальна педагогіка / Соціальна робота : навч. посіб. К. : ІЗМН, 1997.392 с.

3. Рижанова А. О. Розвиток соціальності людини як умова формування громадянського суспільства. Наука $і$ соціальні проблеми суспільства: освіта, культура, духовність : матер. V міжнар. наук.-практ. конф. (м. Харків, 20-21 травня 2008 р.). Х. : ХНПУ ім. Г. С. Сковороди, 2008. С. 98-100.

4. Діти у складних життєвих обставинах: програми i методики соціальнопсихологічної реабілітації дітей, які перебувають у центрі соціально-психологічної реабілітації дітей / керівник авт. колективу А. Г. Зінченко. [Електронний ресурс]. К. : Держ. ін-т сімейної та молодіжної політики, 2013. Режим доступу: file://C:/Users/user/ Downloads/Diti-u-skladnih-zhittievih-obstavinah.pdf.

5. Сосюра М. О. Соціально-педагогічна реабілітація неповнолітніх, які опинилися у складних життєвих обставинах, в умовах центру реабілітації [Електронний ресурс]. Педагогічні науки: теорія, історія, інноваційні технологї. 2015. № 8(52). С. 420-426. Режим доступу: http://nbuv.gov.ua/UJRN/pednauk_2015_8_51

6. Рассказова О. I. Теорія та практика розвитку соціальності учнів в умовах інклюзивної освіти : дис. докт. пед. наук : спец. 13.00.05. Луганськ : ДЗ «Луган. нац. унт ім. Т. Шевченка», 2014. 520 с.

7. Олексюк О. М. Музична педагогіка : навч. посіб. К .: Київ. ун-т ім. Б. Грінченка, 2013. $188 \mathrm{c}$.

8. Вопросы социологического изучения театра : сб. научн. трудов. Л. : ЛГИТМИК им. Н. К. Черкасова, 1979.180 с.

9. Заверико Н. В. Теоретичні засади соціально-педагогічної технології роботи 3 підлітками [Електронний ресурс]. Соціологія. Соціальна робота. Соціальна педагогіка. Управління. 2004. Серія № 11. Вип. 2. Режим доступу: http://enpuir.npu.edu.ua/bitstream/ 123456789/3789/1/Zaveryko.pdf.

10. Шахрай В. М. Театральне мистецтво як чинник оптимізації взаємодії особистості та соціуму [Електронний ресурс]. Народна освіта. 2011. Вип. № 1 (13). Режим доступу: https://www.narodnaosvita.kiev.ua/Narodna_osvita/vupysku/13/statti/shahrai.htm

11. Локарєва Г. В., Стадніченко Н. В. Театральне мистецтво як засіб досягнення позитивних результатів у процесі реабілітації хворих: теоретичний та практичний аспекти [Електронний ресурс]. Вісник Запорізького національного університету. Педагогічні науки. 2009. № 1. С. 95-100. Режим доступу: http://nbuv.gov.ua/UJRN/Vznu_ped_2009_1_21

12. Левчук I. Соціально-психологічний театр у профілактично-корекційній роботі соціального працівника. Social Work and Education. Vol. 6, No. 4. Ternopil-Aberdeen, 2019. pp. 372-381. DOI: 10.25128/2520-6230.19.4.3

13. Дергач М. А. Театральне мистецтво та соціалізація особистості. Соціальна робота в Україні : теорія і практика. 2004. №3 (8). К., 2004. С.57-62.

14. Кремешна Т. Театр як засіб впливу на культурне та соціальне становлення особистості [Електронний ресурс]. Молодь і ринок. 2012. №5 (88). С. 102-105. Режим доступу: file:///C:/Users/user/Downloads/Mir 2012 5 23.pdf.

15. Максимовська Н. О. Анімація засобами мистецтв як напрям соціального виховання. Соціальна педагогіка: теорія та практика. 2011. №2. Луганськ : ЛНУ ім. Т. Шевченка, 2011. С. 38-44.

16. Хендрик О. Ю. Розвиток соціальності людини інформаційного суспільства засобами хореографії. Педагогіка, психологія та медико-біологічні проблеми фізичного виховання і спорту. Харків : ХДАДМ (ХХПІ), 2008. № 10. С. 131-135. 
17. Некрасова Л. М. Театр как вид искусства и его возможности в воспитании школьников [Электронный ресурс]. Педагогика исскуства. 2007. № 1. Режим доступа: http://www.art-education.ru/electronic-journal/teatr-kak-vid-iskusstva-i-ego-vozmozhnosti-vvospitanii-shkolnikov

\section{References:}

1. Bocharova, V. G. (2003). Social'naya pedagogika: dialog nauki i praktiki [Social pedagogy: dialogue of science and practice]. Pedagogika-Pedagogy, 9, 3-9 [in Russian].

2. Koval, L. H., Zvierieva, I. D., Khliebik, S. R. (1997). Sotsialna pedahohika / Sotsialna robota [Social pedagogy/Social work]. Kyiv: IZMN [in Ukrainian].

3. Ryzhanova, A. O. (2008). Rozvytok sotsialnosti liudyny yak umova formuvannia hromadianskoho suspilstva [Development of human sociality as a condition for the formation of civil society]. Proceedings from SSPS '8: $V$ Mizhnarodna naukovo-praktychna konferentsiia «Nauka i sotsialni problemy suspilstva: osvita, kultura, dukhovnist» - The Fifth International Scientific-Practical Conference «Science and Social Problems of Society: Education, Culture, Spirituality». (pp. 98-100). Kharkiv: KhNPU im. H. S. Skovorody. [in Ukrainian].

4. Zinchenko, A. H. (Eds.). (2013). Dity u skladnykh zhyttievykh obstavynakh: prohramy i metodyky sotsialno-psykholohichnoi reabilitatsii ditei, yaki perebuvaiut u tsentri sotsialnopsykholohichnoi reabilitatsii ditei [Children at the foldable living conditions: programs and methods of social and psychological rehabilitation of children, which are overloaded at the center of social and psychological rehabilitation of children]. Kyiv: SI of Family and Youth Policy. Retrieved from file:///C:/Users/user/ Downloads/Diti-u-skladnih-zhittievih-obstavinah.pdf [in Ukrainian].

5. Sosiura, M. O. (2015). Sotsialno-pedahohichna reabilitatsiia nepovnolitnikh, yaki opynylysia u skladnykh zhyttievykh obstavynakh, v umovakh tsentru reabilitatsii [Sociopedagogical rehabilitation of juveniles who find themselves in difficult life circumstances in the rehabilitation center]. Pedahohichni nauky: teoriia, istoriia, innovatsiini tekhnolohii Pedagogical sciences: theory, history, innovative technologies, 8(52), 420-426. Retrieved from http://nbuv.gov.ua/UJRN/pednauk_2015_8_51 [in Ukrainian].

6. Rasskazova, O. I. (2014). Teoriia ta praktyka rozvytku sotsialnosti uchniv v umovakh inkliuzyvnoi osvity [Theory and practice of development of students' sociality in the conditions of inclusive education]. Doctor's thesis. Luhansk: State Institution «Luhansk Taras Shevchenko National University» [in Ukrainian].

7. Oleksiuk, O. M. (2013). Muzychna pedahohika [Music pedagogy]. Kyiv: Kyiv. un-t im. B. Hrinchenka, [in Ukrainian].

8. Voprosy sociologicheskogo izucheniya teatra [Questions of the sociological study of theater] (1979). Leningrad: LGITMIK im. N. K. Cherkasova [in Russian].

9. Zaveryko, N. V. (2004). Teoretychni zasady sotsialno-pedahohichnoi tekhnolohii roboty $\mathrm{z}$ pidlitkamy [Theoretical principles of socio-pedagogical technology of working with adolescents]. Sotsiolohiia. Sotsialna robota. Sotsialna pedahohika. Upravlinnia - Sociology. Social work. Social pedagogy. Management, $11(2$ Retrieved from http://enpuir.npu.edu.ua/bitstream/ 123456789/3789/1/Zaveryko.pdf [in Ukrainian].

10. Shakhrai, V. M. (2011). Teatralne mystetstvo yak chynnyk optymizatsii vzaiemodii osobystosti ta sotsiumu [Theatrical art as a factor in optimizing the interaction of the individual and society]. Narodna osvita - Public education, 1(13). Retrieved from https://www.narodnaosvita.kiev.ua/Narodna_osvita/vupysku/13/ statti/shahrai.htm [in Ukrainian].

11. Lokarieva, H. V., Stadnichenko, N. V. (2009). Teatralne mystetstvo yak zasib dosiahnennia pozytyvnykh rezultativ u protsesi reabilitatsii khvorykh: teoretychnyi ta praktychnyi aspekty [Theatrical art as a means of achieving positive results in the process of rehabilitation of patients: theoretical and practical aspects]. Visnyk Zaporizkoho natsionalnoho universytetu. Pedahohichni nauky - Bulletin of Zaporizhia National University. Pedagogical sciences, 1, 95-100. 
Retrieved from http://nbuv.gov.ua/UJRN/Vznu_ped_2009_1_21 [in Ukrainian].

12. Levchuk I. (2019). Sotsialno-psykholohichnyi teatr u profilaktychno-korektsiinii roboti cotsialnoho pratsivnyka [Socio-psychological theater in the preventive and corrective work of a social worker]. Social Work and Education, 6 (4), 372-381. DOI: 10.25128/2520-6230.19.4.3. [in Ukrainian].

13. Derhach, M. A. (2004). Teatralne mystetstvo ta sotsializatsiia osobystosti [Theatrical art and socialization of the individual]. Sotsialna robota $v$ Ukraini: teoriia i praktyka - Social work in Ukraine: theory and practice, 3 (8), 57-62. [in Ukrainian].

14. Kremeshna, T. (2012). Teatr yak zasib vplyvu na kulturne ta sotsialne stanovlennia osobystosti [Theater as a means of influencing the cultural and social development of the individual]. Molod $i$ rynok. - Youth and the market, №5 (88), 102-105. Retrieved from file:///C:/Users/user/Downloads/Mir_2012_5_23.pdf. [in Ukrainian].

15. Maksymovska, N. O. (2011). Animatsiia zasobamy mystetstv yak napriam sotsialnoho vykhovannia [Animation by means of arts as a direction of social education]. Sotsialna pedahohika: teoriia ta praktyka - Social pedagogy: theory and practice, 2, 38-44. Luhansk: LNU im. T. Shevchenka [in Ukrainian].

16. Khendryk, O. Yu. (2008). Rozvytok sotsialnosti liudyny informatsiinoho suspilstva zasobamy khoreohrafii [Development of human sociality of the information society by means of choreography]. Pedahohika, psykholohiia ta medyko-biolohichni problemy fizychnoho vykhovannia $i$ sportu - Pedagogy, psychology and medical and biological problems of physical education and sports (Vols. 10), (pp. 131-135). S. S. Yermakov (Ed.). Kharkiv: KhDADM [in Ukrainian].

17. Nekrasova, L. M. (2007). Teatr kak vid iskusstva i ego vozmozhnosti v vospitanii shkol'nikov [Theater as an art form and its possibilities in educating schoolchildren]. Pedagogika isskustva - Art Pedagogy, 1. Retrieved from http://www.art-education.ru/electronic-journal/teatrkak-vid-iskusstva-i-ego-vozmozhnosti-v-vospitanii-shkolnikov [in Russian]. 